\title{
EFFECTS OF MICROCRYSTALLINE CELLULOSE ON SOME PERFORMANCE PROPERTIES OF CHITOSAN AEROGELS
}

\author{
Ertan Ozen ${ }^{1}$ \\ https://orcid.org/0000-0002-2593-0146 \\ Nadir Yildirim ${ }^{2}$ \\ https://orcid.org/0000-0003-2751-9593 \\ Berk Dalkilic ${ }^{3,4}$ \\ https://orcid.org/0000-0002-0457-1244 \\ Mehmet E. Ergun ${ }^{4}$ \\ https://orcid.org/0000-0002-9938-7561
}

\begin{abstract}
The aim of this research was to investigate the effect of the microcrystalline cellulose reinforcement on some physical, mechanical, thermal, and morphological properties of the chitosan aerogels. The bio-based chitosan aerogels were produced using chitosan as a matrix and the microcrystalline cellulose as a reinforce material through the freeze-drying method. The aerogel suspensions were prepared in five different ratios to investigate the effect of microcrystalline cellulose content. The density, porosity, thermogravimetric analysis, and compressive resistance tests were conducted according to relevant standards. Morphological properties were investigated using a scanning electron microscope. The introduction of microcrystalline cellulose significantly improved the compressive resistance, thermal properties $\left(\mathrm{T}_{\text {onset }}\right.$ and $\left.\mathrm{T}_{\% 50}\right)$ of the chitosan aerogels. The optimum performance properties determined as $0,12 \mathrm{MPa}$ for compressive resistance, $0,27 \mathrm{MPa}$ for compressive modulus, $292,45^{\circ} \mathrm{C}$ for $\mathrm{T}_{\text {onset }}$ and $365^{\circ} \mathrm{C}$ for $\mathrm{T}_{\% 550}$. According to scanning electron microscope images, aerogels showed microporous structure as expected. As a result, the bio-based chitosan aerogels reinforced with microcrystalline cellulose were successfully manufactured. The mechanical and thermal properties including compressive resistance, compressive modulus, $\mathrm{T}_{\text {onset }}$ and $\mathrm{T}_{\% 50}$ of chitosan- microcrystalline cellulose aerogels found promising.
\end{abstract}

Keywords: Aerogels, bio-based, compressive resistance, chitosan, microcrystalline cellulose, thermogravimetric analysis, scanning electron microscope.

\section{INTRODUCTION}

The petroleum-based plastics; bottles, cups are carried to the oceans through the winds. These plastics chemically degrade once exposed to UV radiation. Also, the shear forces created by the waves break plastics down into tiny pieces. These tiny polystyrene based pieces were swallowed by fishes and other sea animals (Smith et al. 2018). Polystyrene, one of the major raw material used for manufacturing plastics, are not full

\footnotetext{
${ }^{1}$ Muğla Sitkı Koçman University, Faculty of Technology, Department of Woodworking Industrial Engineering, Muğla, Turkey.

${ }^{2}$ Bursa Technical University, Faculty of Forestry, Department of Forest Industry Engineering, Bursa, Turkey.

${ }^{3}$ Sinop University, Ayanc1k Vocational School, Department of Design, Sinop, Turkey.

${ }^{4}$ Alaaddin Keykubat University, Akseki Vocational School, Department of Forestry, Antalya, Turkey.

•Corresponding author: bdalkilic@sinop.edu.tr
}

Received: 04.03.2020 Accepted: 21.12.2020 
recyclable and creates land-fill (Mathias et al. 2011). In this regard, bio-based polymers are getting more attractive for researchers and manufacturers as an alternative to polystyrene based products (Gomes et al. 2017).

Microcrystalline cellulose (MCC) is mostly used as a filler because of its outstanding properties such as high crystallinity, high strength, low thermal expansion coefficient, low cost, low density, biodegradability, and no environmental pollution after disposal (Chen et al. 2020). MCC can be produced from any material having a high content of cellulose by acid and alkali hydrolysis (Trache et al. 2016), ultrasonic and extrusion methods (Abdullah et al. 2016), steam explosion and radiation enzymatic process (Henriksson et al. 2007) in order to use in pharmaceutical, cosmetic, food, packaging and polymer composite industries. These reported methods are expensive as the energy consumption for the treatment is high in pressure processes like a steam explosion and pressure extrusion (Katakojwala and Mohan 2020). The production cost and less yield might adversely affect the MCC market price development (Sundarraj and Ranganathan 2018). MCC is available at the market price of $\approx 4 \$ / \mathrm{kg}$, which is comparable to or less than some materials like glass or aramid (Trache et al. 2016). In this study MCC preferred because of its high crystallinity, high availability, biodegradability and comparable price. The crystallinity of commercial MCC reported as $78 \%$ by (El-Sakhawy and Hassan 2007) and $85 \%$ by (Adel et al. 2011). The crystallinity affects the thermal stability of the final product as reported by (Wang et al. 2017). There are also limited studies focusing on MCC based composites.

Chitosan as a bio-based polymer has many application areas including but not limited to biomedical, water purification, insulation, and packaging. However, its weak performance properties require to be reinforced with materials having higher thermal and mechanical properties. Many studies focused on blending chitosan with cellulose and its derivatives. For example: (Wang et al. 2017) produced chitosan and nanofibrillated cellulose (NFC) based nanocomposite foam with different ratios by freeze-drying technique. The chitosan-NFC nanocomposite foams showed a highly efficient oil/water separation capacity. (Olorunsola et al. 2017) evaluated chitosan microcrystalline cellulose blends as direct compression excipients. (Stefanescu et al. 2012) produced blend membranes using chitosan and cellulose in trifluoroacetic acid solution. They reported that chitosan/cellulose membranes can be used for wound dressing as it has the potential to prevent wound based on antimicrobial capability against Escherichia coli and Staphylococcus aureus. (Altuntas and Aydemir 2019) investigated effect of wood flour on the performance properties of poly (L-lactic acid)-chitosan biopolymer composites. They reported that wood flour improved all the mechanical and thermal properties of PLA-chitosan. (Kim et al. 2011) produced bacterial cellulose (BC)-chitosan scaffolds composite by submerging wet bacterial cellulose pellicle in chitosan solution followed by freeze-drying. (Bhandari et al. 2017) produced $\mathrm{CNF}$ aerogels by using freeze-drying method and introduced as new possible carriers for oral controlled drug delivery system. (Mishra et al. 2017) produced and characterized CNF by using protein-based biomass. On the other hand, gelatin, starch and cellulose were extensively studied to produce bio-based materials for many applications. (Demitri et al. 2014) developed sodium salt of carboxymethyl cellulose (CMCNa) and polyethylene glycol diacrylate (PEGDA700) based foams. They reported that foams with better mechanical properties and water absorption capacity can be produced using $20 \%$ Poly (ethylene glycol) diacrylate (PEGDA). (Mishra et al. 2019) studied toxicity-related issues of CNF. (Czaja et al. 2007) used bacterial nanocellulose (BNC) membranes for severe second-degree burns. They found that BNC membranes healed the wounds faster than conventional wound dressings. (Yildirim et al. 2014) produced biodegradable foam using cellulose nanofibrils (CNF) and industrial cornstarch by the freeze-dying technique. They reported that optimum performance properties were determined when $6 \%$ starch $+1,5 \% \mathrm{CNF}$ added.

In this research, $\mathrm{MCC}$ reinforced chitosan aerogels were designed and manufactured using the freeze-drying technique. The aim of this research was to investigate the effect of the MCC reinforcement on some physical, mechanical, thermal, and morphological properties of the chitosan aerogels.

\section{MATERIALS AND METHODS}

\section{Materials}

Crab shell-based chitosan (CAS: 9012-76-4) having properties such as medium molecular weight, $60 \%$ oligosaccharide, average Mn 5000 and $>75 \%$ deacetylation was supplied from Sigma-Aldrich (Germany). Microcrystalline cellulose $\mathrm{C}_{12} \mathrm{H}_{22} \mathrm{O}_{11}$ (CAS: 9004-34-6) having properties such as $0,27 \mathrm{~g} / \mathrm{mL}$ to $0,34 \mathrm{~g} / \mathrm{mL}$ bulk density, 5,0 pH - 7,5 pH was supplied from Tito Company (Turkey). 


\section{Design and manufacturing of aerogels}

Medium molecular weight chitosan and microcrystalline cellulose (MCC) were used to manufacture biobased aerogels. The reinforcement was performed in five (5) different ratios as shown in Table 1.

The manufacturing method reported by Svagan et al. (2008) and Yildirim et al. (2014) was used with slight changes. For each individual test sample, $2 \mathrm{~g}$ chitosan was dissolved in $1 \%$ acetic acid-water solution using a magnetic stirrer at $41,8 \mathrm{rad} / \mathrm{s}$ for 2 hours. Then, the MCC was added to the suspension depending on pre-determined ratios and shear-mixed for another 30 minutes at $31,4 \mathrm{rad} / \mathrm{s}$.

Table 1: Manufacturing design of chitosan-MCC aerogels.

\begin{tabular}{|c|c|c|c|c|}
\hline Group & $\begin{array}{c}\text { Chitosan } \\
(\mathrm{g})\end{array}$ & $\begin{array}{c}\text { MCC } \\
(\mathrm{g})\end{array}$ & $\begin{array}{c}\text { Distilled water } \\
(\mathrm{mL})\end{array}$ & $\begin{array}{c}\text { Acetic-acid } \\
(\mathrm{mL})\end{array}$ \\
\hline 1 & 2 & 0 & 99 & 1 \\
\hline 2 & 2 & 2 & 99 & 1 \\
\hline 3 & 2 & 4 & 99 & 1 \\
\hline 4 & 2 & 6 & 99 & 1 \\
\hline 5 & 2 & 8 & 99 & 1 \\
\hline
\end{tabular}

The final suspensions were poured into the petri cups and located in the freezer at $-80{ }^{\circ} \mathrm{C}$ for 24 hours. The frozen suspensions were sublimated under 800 mbar pressures for 72 hours using Thermo ModulyoD brand freeze-dryer. The demonstration of the manufacturing process is given in Figure 1.

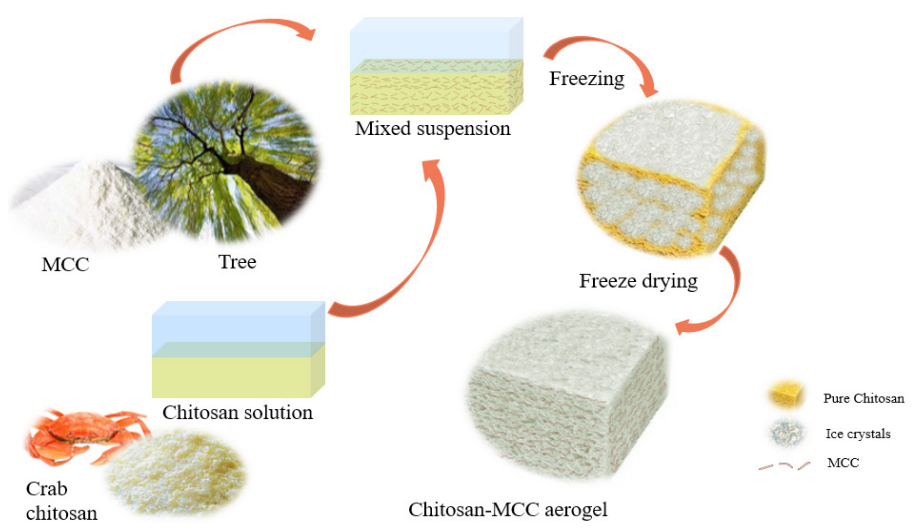

Figure 1: Manufacturing process of chitosan-MCC aerogels.

\section{Density determination}

The six (6) specimens with $150 \mathrm{~mm}$ x $150 \mathrm{~mm}$ x $25 \mathrm{~mm}$ dimensions from each group were prepared for the measurements (ASTM C303-10e1 2016). The measured mass (m, kg) was divided to the measured volume $\left(\mathrm{v}, \mathrm{m}^{3}\right)$ to calculate the density (Equation 1$)$.

$$
d=m / v
$$

\section{Porosity determination}

The porosity (void fraction), the ratio of pore volume to the total volume of aerogels, was calculated using the porosimetry method (Gibson and Ashby 1997) as provided in Equation 2. 


$$
I=\left(\frac{\text { Pbulk }}{\text { Pparticle }}-1\right) \times 100
$$

Where, I: porosity, P bulk: density of foam, P particle: density of particle

\section{Morphological structure investigation}

The morphological properties of the aerogels were investigated using JSM-7600F brand scanning electron microscopy (SEM). The samples were resized using a razor blade and pasted onto stubs. The gold-palladium (Au: Pd) sputter coating was applied to the samples and imaging was performed using an acceleration voltage of $15 \mathrm{kV}$.

\section{Compression tests}

A total of five (5) samples with $60 \mathrm{~mm}$ diameter and $30 \mathrm{~mm}$ thickness from each group were prepared and tested as shown in Figure 2. Each sample was compressed at a rate of $1,2 \mathrm{~mm} / \mathrm{min}$ for 90 seconds (ASTM C165-07 2017). Compressive resistance (at $40 \%$ ) and compressive modulus (at $40 \%$ ) were calculated. The compression tests were conducted under laboratory conditions $\left(25{ }^{\circ} \mathrm{C} \pm 2{ }^{\circ} \mathrm{C}\right.$ temperature and $50 \%$ relative humidity). The test samples were conditioned $\left(20^{\circ} \mathrm{C} \pm 2{ }^{\circ} \mathrm{C}\right.$ temperature and $65 \%$ relative humidity) to reach the constant moisture (hygroscopic equilibrium of $12 \%$ ) prior to testing.

(a)

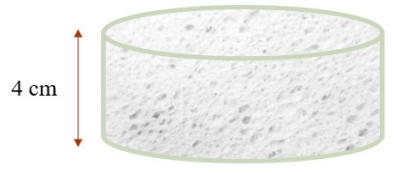

(c)

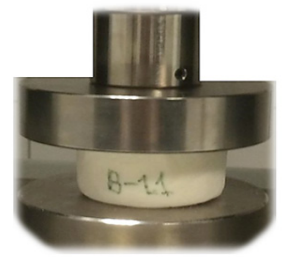

(b)

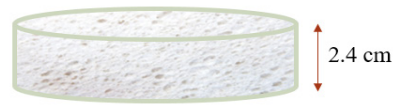

(d)

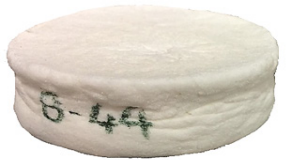

Figure 2: Demonstration of compression tests; (a) sample demonstration (before compression testing), (b) sample demonstration (after compression testing) (c) actual compression loading, and (d) actual sample (after compression testing).

\section{Thermogravimetric analysis (TGA)}

The total of five (5) samples from each group grinded into powders having total weight values vary between $6 \mathrm{mg}$ to $10 \mathrm{mg}$. Once the samples prepared, the Thermogravimetric analysis was performed from $38^{\circ} \mathrm{C}$ to $600{ }^{\circ} \mathrm{C}$ with a $10{ }^{\circ} \mathrm{C}$ increase per min. using PerkinElmer TGA 4000 Thermal Gravimetric Analyzer. The weight loss of samples as a function of temperature was recorded.

\section{Statistical analysis}

The density, porosity, compressive resistance and compression modulus data were compared by performing one-way Means/ANOVA to control if there was a significant difference (alpha $=0,01)$ or not. Significant differences among groups were calculated by using Tukey-Kreamer Honestly Significant Differences (HSD) test (alpha $=0,05)$. 


\section{RESULTS AND DISCUSSION}

The results followed by discussions are provided under following subsections.

\section{Density and porosity}

The density and porosity results and their statistical comparisons are given in Table 2.

Table 2: The density and porosity of developed aerogels.

\begin{tabular}{|c|c|c|}
\hline Group & Density $\left(\mathrm{kg} / \mathrm{m}^{3}\right)$ & Porosity $(\%)$ \\
\hline 1 & $30(5,95) \mathrm{C}$ & $94,73(0,33) \mathrm{A}$ \\
\hline 2 & $50(3,06) \mathrm{C}$ & $80,34(0,75) \mathrm{B}$ \\
\hline 3 & $80(14,48) \mathrm{B}$ & $72,28(5,55) \mathrm{C}$ \\
\hline 4 & $90(16,82) \mathrm{AB}$ & $69,18(7,49) \mathrm{C}$ \\
\hline 5 & $110(3,14) \mathrm{A}$ & $62,30(1,90) \mathrm{D}$ \\
\hline
\end{tabular}

Values put in the parentheses: The coefficient of variation.

A, B, C, D letters indicate the significant differences between the groups.

The density of chitosan-MCC aerogels was determined to change between $30 \mathrm{~kg} / \mathrm{m}^{3}-110 \mathrm{~kg} / \mathrm{m}^{3}$. There is a considerable effect of solid content on the final density (Table 2). As expected; an increase in solid content within the same volume increased in the density. The addition of MCC decreased the porosity from $94,73 \%$ to $62,30 \%$.

\section{Morphology}

The MCC SEM images and the particle size measurements were provided in Figure 3. The MCC particle sizes determined ranging between $45,8 \mu \mathrm{m}$ to $257 \mu \mathrm{m}$ (Figure 3). As given in Figure 3, MCC is composed of aggregate bundles of multi-sized cellulose micro particles that are strongly bonded to each other.

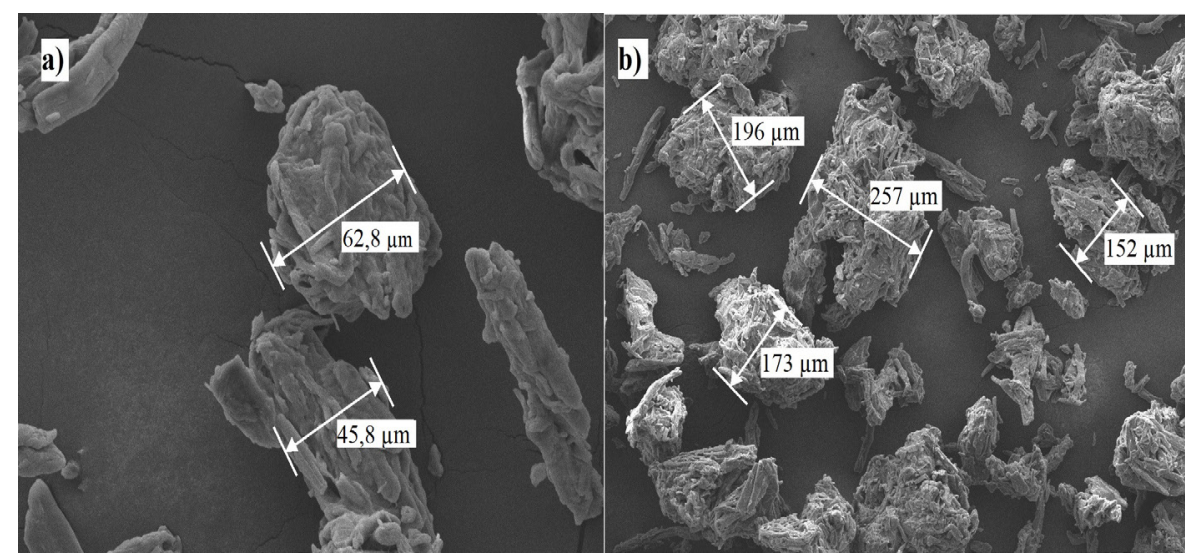

Figure 3: The SEM image of pure MCC powder; (a) minimum measured diameter of MCC particles, (b) maximum measured diameter of MCC particles.

The morphological properties of chitosan-MCC aerogels were investigated to understand their microstructure (Figure 4). The aerogels microstructure showed porous structures interconnected through cell walls (sheets). As shown in Figure 4c, Figure 4d, Figure 4e and Figure 4f; MCC aggregate bundles bonded to chitosan sheets randomly. Previous studies also showed similar structures; (Wang et al. 2017) investigated the microstructure of chitosan-nanofibrillated cellulose (NFC) foams and showed that the NFC bonded to the cell walls/sheets randomly. 

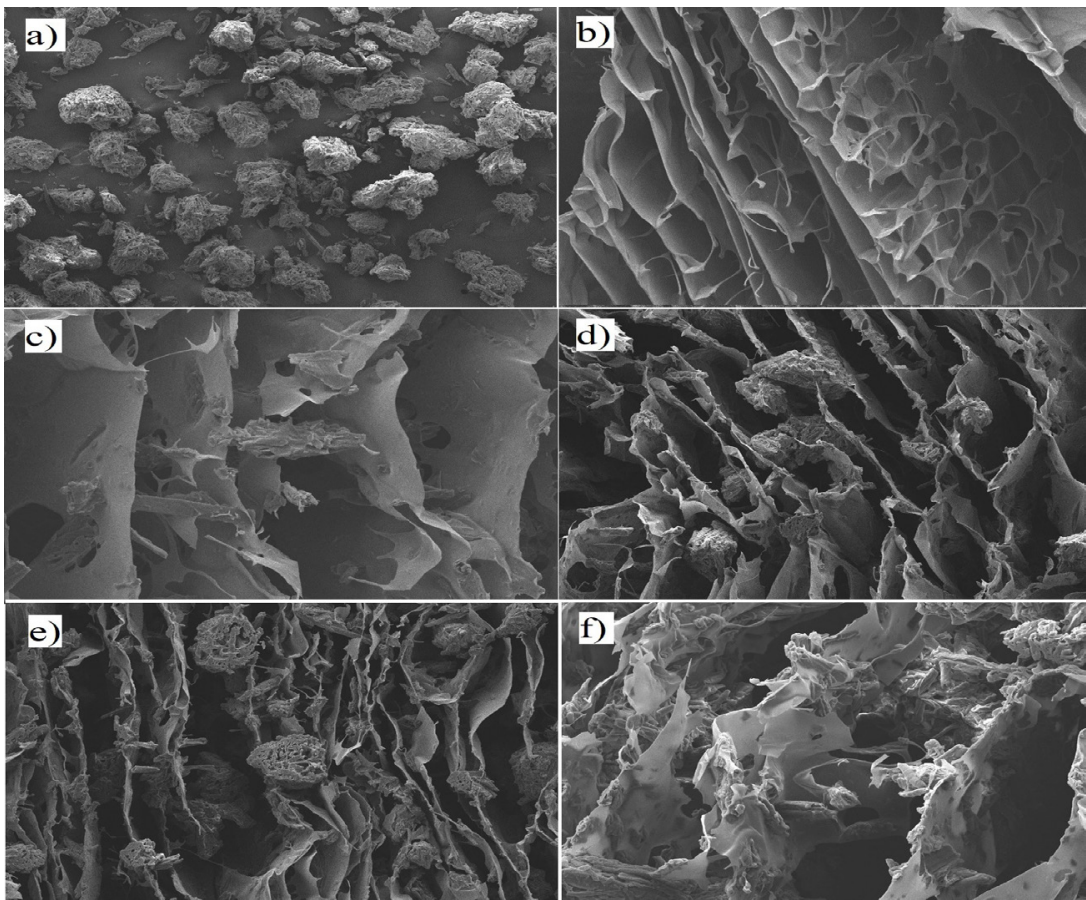

Figure 4: The SEM images of aerogels; (a) pure microcrystalline cellulose powder, (b) pure chitosan powder, (c) group 2, (d) group 3, (e) group 4, (f) group 5.

\section{Compressive resistance and modulus}

The compressive resistance and modulus of chitosan-MCC aerogels and relevant studies for comparison purposes are given in Table 3.

Table 3: The compressive resistance and modulus of the aerogels and comparison with existing studies.

\begin{tabular}{|l|c|c|c|}
\hline $\begin{array}{l}\text { Groups and relevant } \\
\text { studies }\end{array}$ & $\begin{array}{c}\text { Compressive } \\
\text { Resistance } \\
(\mathbf{M P a})\end{array}$ & $\begin{array}{c}\text { Compressive } \\
\text { Modulus } \\
(\mathbf{M P a})\end{array}$ & $\begin{array}{c}\text { Density } \\
\left(\mathbf{k g} / \mathbf{m}^{\mathbf{3}}\right)\end{array}$ \\
\hline 1 & $0,04(15,27) \mathrm{D}$ & $0,10(11,83) \mathrm{C}$ & $30(5,95) \mathrm{C}$ \\
\hline 2 & $0,05(17,33) \mathrm{C}$ & $0,11(20,97) \mathrm{BC}$ & $50(3,06) \mathrm{C}$ \\
\hline 3 & $0,08(26,27) \mathrm{B}$ & $0,20(28,34) \mathrm{AB}$ & $80(14,48) \mathrm{B}$ \\
\hline 4 & $0,08(8,75) \mathrm{BC}$ & $0,20(15,50) \mathrm{AB}$ & $90(16,82) \mathrm{AB}$ \\
\hline 5 & $0,12(9,95) \mathrm{A}$ & $0,27(14,21) \mathrm{A}$ & $110(3,14) \mathrm{A}$ \\
\hline $0,5 \% \mathrm{CNF}+0,5 \%$ Starch $^{\mathrm{I}}$ & 0,14 & 0,015 & 13 \\
\hline $1 \% \mathrm{CNF}$ I & 0,35 & 0,03 & 14 \\
\hline $1,5 \% \mathrm{CNF}+3 \% \mathrm{Starch}^{\mathrm{I}}$ & 2,75 & 0,49 & 53 \\
\hline $1,5 \% \mathrm{CNF}+6 \% \mathrm{Starch}^{\mathrm{I}}$ & 3,33 & 0,907 & 76 \\
\hline $\mathrm{CNF}$ & 0,23 & 2,8 & 105 \\
\hline $\mathrm{CNF}$ & - & 1,76 & 63 \\
\hline $2 \% \mathrm{CNF}$ Foam ${ }^{\mathrm{IV}}$ & 0,013 & - & 100 \\
\hline $0,5 \% \mathrm{CNF}+1,5 \% \mathrm{CMF}^{\mathrm{IV}}$ & 0,01 & - & 13 \\
\hline
\end{tabular}

Values put in the parentheses: The coefficient of variation. A, B, C, D letters indicate the significant differences between the groups. CNF: Cellulose nanofibril, CMF: Cellulose microfibril, MCC: Microcrystalline cellulose. 'Yildirim et al. (2014), "ISehaqui et al. (2011),

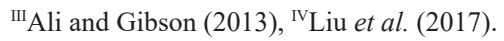


The addition of MCC increased the compressive resistance and compressive modulus. However, there are no statistical differences between the compressive resistance of Group 3 and Group 4. The highest compressive resistance obtained from Group 5. The lowest compressive resistance obtained from pure chitosan aerogels as expected.

\section{Thermogravimetric analysis}

The Thermogravimetric analysis of the chitosan-MCC aerogels are shown in Figure 5.

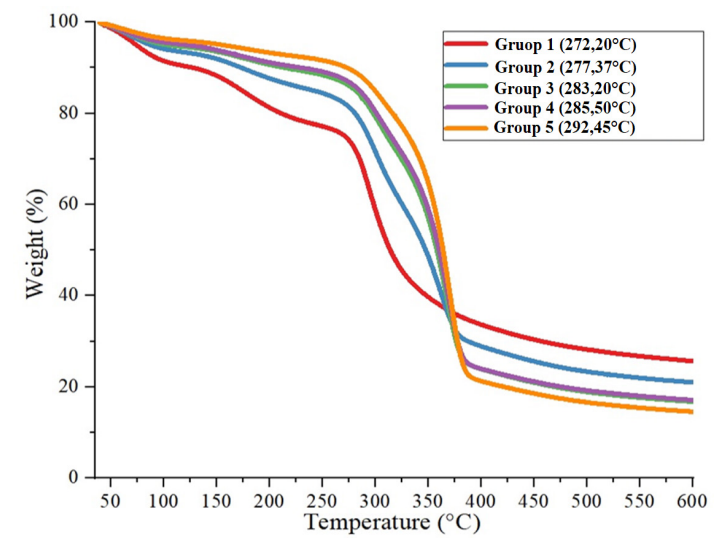

Figure 5: The TGA curve of chitosan-MCC aerogels.

According to TGA curve of chitosan aerogels (Group 1), the weight loss occurred at three steps with a maximum rate of weight loss at $341,3{ }^{\circ} \mathrm{C}$. The onset of the peak at around $272,2{ }^{\circ} \mathrm{C}$ showed the starting point of decomposition. Typically, TGA curves of chitosan-MCC aerogels, the weight loss occurred at three steps with a maximum rate of weight loss at $365^{\circ} \mathrm{C}$. The degradation occurred between $200{ }^{\circ} \mathrm{C}$ and $400{ }^{\circ} \mathrm{C}$. The first loss of weight of aerogels is due to the evaporation of adsorbed water. The introduction of MCC consistently increased $\mathrm{T}_{\text {onset }}$ and $\mathrm{T}_{\% 50}$ of chitosan aerogels as shown in Table 4 . The highest $\mathrm{T}_{\text {onset }}\left(292,45^{\circ} \mathrm{C}\right)$ and $\mathrm{T}_{\% 50}(365$ ${ }^{\circ} \mathrm{C}$ ) determined when $8 \mathrm{~g} \mathrm{MCC}$ introduced (Table 4.).

Derivative (DTG) curves were obtained from TGA curve as a function of time. As shown in Figure 6, two peaks were recorded for chitosan-MCC aerogels as expected.

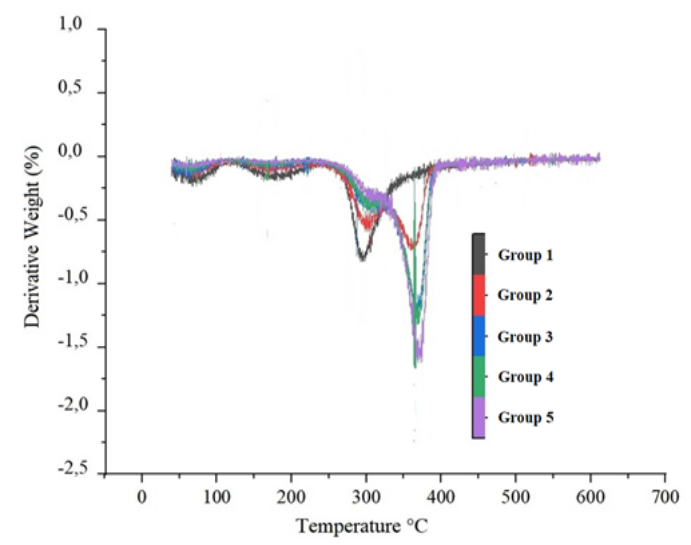

Figure 6: The dTGA of chitosan-MCC aerogels.

The thermal properties of chitosan-MCC aerogels and other relevant studies are compared in Table 4. 
Table 4: The thermal properties of chitosan-MCC aerogels and comparison with existing studies.

\begin{tabular}{|c|c|c|c|c|c|}
\hline $\begin{array}{l}\text { Groups and } \\
\text { relevant } \\
\text { studies }\end{array}$ & $\begin{array}{l}\mathrm{T}_{\text {onset }} \\
\left({ }^{\circ} \mathrm{C}\right)\end{array}$ & $\begin{array}{l}\mathrm{T}_{50 \%} \\
\left({ }^{\circ} \mathrm{C}\right)\end{array}$ & $\begin{array}{c}1^{\text {st }} \text { dTGA } \\
\text { Temperature } \\
\left({ }^{\circ} \mathrm{C}\right)\end{array}$ & $\begin{array}{c}2^{\text {nd }} \text { dTGA } \\
\text { Temperature } \\
\left({ }^{\circ} \mathrm{C}\right)\end{array}$ & $\begin{array}{c}\text { Residue } \\
(\%)\end{array}$ \\
\hline 1 & 272,2 & 341,3 & 293,99 & - & 25,4 \\
\hline 2 & 277,3 & 347,79 & 301,53 & 361,7 & 20,8 \\
\hline 3 & 283,2 & 358,36 & 309,36 & 367,09 & 16,6 \\
\hline 4 & 285,5 & 360,38 & 311,91 & 368,93 & 16 \\
\hline 5 & 292,4 & 365 & 316,18 & 371 & 14,4 \\
\hline $\begin{array}{l}1 \% \mathrm{CNF} \\
\text { Foam }{ }^{\mathrm{I}}\end{array}$ & 277 & 335 & 339 & - & 15,3 \\
\hline $\begin{array}{l}1,5 \% \mathrm{CNF}+ \\
3 \% \text { Starch I }^{\mathrm{I}}\end{array}$ & 260 & 308 & 304 & - & 8,7 \\
\hline $\begin{array}{l}1,5 \% \mathrm{CNF}^{+} \\
6 \% \mathrm{Starch}^{\mathrm{I}}\end{array}$ & 255 & 318 & 310 & - & 11,6 \\
\hline $\begin{array}{l}7,5 \% \text { Starch } \\
\text { Foam I }\end{array}$ & 259 & 300 & 295 & - & 14,9 \\
\hline $\begin{array}{l}\text { Pure MCC } \\
\text { PolymerII }\end{array}$ & 330 & - & - & - & - \\
\hline $\begin{array}{l}\text { Pure } \\
\text { Chitosan } \\
\text { Polymer III }\end{array}$ & 250 & - & - & - & - \\
\hline
\end{tabular}

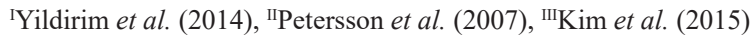

CNF: Cellulose nanofibril, CMF: Cellulose microfibril, MCC: Microcrystalline cellulose.

The results obtained from thermogravimetric analyses found comparable with relevant literature studies. The $\mathrm{T}_{\%, 50}$ found between $341,3{ }^{\circ} \mathrm{C}$ and $365^{\circ} \mathrm{C}$. (Wang et al. 2017) found the $\mathrm{T}_{\% 50}$ between $300{ }^{\circ} \mathrm{C}$ and $350{ }^{\circ} \mathrm{C}$ for chitosan-CNF foams. (Yildirim et al. 2014) found the results between $300{ }^{\circ} \mathrm{C}$ and $335{ }^{\circ} \mathrm{C}$ for CNF-starch foams. (Wang et al. 2017) found the first dTGA temperature between $300{ }^{\circ} \mathrm{C}$ and $359{ }^{\circ} \mathrm{C}$ for chitosan-CNF foams. Similarly, the first dTGA temperature of chitosan-MCC aerogels found between $293,99{ }^{\circ} \mathrm{C}$ and 316,18 ${ }^{\circ} \mathrm{C}$. In the other study, performed by (Lim et al. 2015) the onset temperature value was found $250{ }^{\circ} \mathrm{C}$. The variety in the onset and decomposition temperatures can be explained with the different sources of the used materials.

\section{CONCLUSIONS}

This research focused on the design and development of bio-based aerogels. Due to chitosan's low performance properties, another biopolymer; MCC, was used as a reinforcing material. As a result, chitosan and MCC found miscible blends to an extent. The randomly dispersed MCC powders were clearly observed on the aerogels reinforced with $8 \mathrm{~g}$ MCC. The introduction of MCC significantly improved the compressive resistance, modulus and $\mathrm{T}_{\text {onset }}, \mathrm{T}_{\% 50}$ of the chitosan aerogels. However, increasing the MCC amount from $4 \mathrm{~g}$ to $6 \mathrm{~g}$ didn't change the compressive resistance and compression modulus of the aerogels. The optimum performance properties were determined when $8 \mathrm{~g} \mathrm{MCC}$ introduced to the chitosan matrix. The aerogels produced from chitosan and MCC may have a wide range of applications, including as rigid packaging material. The use of biomaterials may reduce the use of petroleum-based products and reduce the landfill.

\section{ACKNOWLEDGMENTS}

We would like to thank to members of Faculty of Fisheries at Mugla Sitki Kocman University for their assistance in the manufacturing of the aerogels. We would like to also thank to Faculty of Forestry members at Bursa Technical University for their assistance in the testing of the aerogels.

\section{REFERENCES}

Abdullah, M.; Nazir, M.; Raza, M.; Wahjoedi, B.; Yussof, A. 2016. Autoclave and ultra-sonication treatments of oil palm empty fruit bunch fibers for cellulose extraction and its polypropylene composite properties. J Clean Prod 126: 686-697. https://doi.org/10.1016/j.jclepro.2016.03.107 
Adel, A.; Abd. El-Wahab Z.; Ibrahim, A.; Al-Shemy, M. 2011. Characterization of microcrystalline cellulose prepared from lignocellulosic materials. Part II: Physicochemical properties. Carbohydr Polym 83(2): 676-687. https://doi.org/10.1016/j.carbpol.2010.08.039

Ali, Z.M.; Gibson, L.J. 2013. The structure and mechanics of nanofibrillar cellulose foams. Soft Matter 9(5): 1580-1588. https://doi.org/10.1039/C2SM27197D

Altuntas, E.; Aydemir, D. 2019. Effects of wood flour on the mechanical, thermal and morphological properties of poly (L-lactic acid)-chitosan biopolymer composites. Maderas-Cienc Tecnol 21(4): 611-618. http://dx.doi.org/10.4067/S0718-221X2019005000416

ASTM. 2016. Standard Test Method for Dimensions and Density of Preformed Block and BoardType Thermal Insulation. ASTM. C303-10e1. 2016. ASTM International: West Conshohocken, PA, USA. https://doi.org/10.1520/C0303-10R16E01

ASTM. 2017. Standard Test Method for Measuring Compressive Properties of Thermal Insulations. ASTM. C165-07. 2017. ASTM International: West Conshohocken, PA, USA. https://doi.org/10.1520/C016507R17

Bhandari, J.; Mishra, H.; Mishra, P.; Wimmer, R.; Ahmad, F.; Talegaonkar, S. 2017. Cellulose nanofiber aerogel as a promising biomaterial for customized oral drug delivery. Int J Nanomedicine 12: 2021-2031. https://doi.org/10.2147/IJN.S124318

Chen, J.; Wang, X.; Long, Z.; Wang, S.; Zhang, J.; Wang, L. 2020. Preparation and performance of thermoplastic starch and microcrystalline cellulose for packaging composites: Extrusion and hot pressing. Int J Biol Macromol 165: 2295-2302. https://doi.org/10.1016/j.ijbiomac.2020.10.117

Czaja, W.K.; Young, D.J.; Kawecki, M.; Brown, R.M. 2007. The future prospects of microbial cellulose in biomedical applications. Biomacromolecules 8(1): 1-12. https://doi.org/10.1021/bm060620d

Demitri, C.; Giuri, A.; Raucci, M.G.; Giugliano, D.; Madaghiele, M.; Sannino, A.; Ambrosio, L. 2014. Preparation and characterization of cellulose-based foams via microwave curing. Interface Focus 4(1): 20130053. https://doi.org/10.1098/rsfs.2013.0053

El-Sakhawy, M.; Hassan, M. 2007. Physical and mechanical properties of microcrystalline cellulose prepared from agricultural residues. Carbohydr Polym 67(1): 1-10. https://doi.org/10.1016/j.carbpol.2006.04.009

Gibson, L.J.; Ashby, M.F. 1997. Cellular Solids; Structure and Properties. Cambridge University Press: Cambridge, United Kingdom. https://doi.org/10.1017/CBO9781139878326

Gomes, L.; Paschoalin, V.M.F.; Del Aquila, E.M. 2017. Chitosan nanoparticles: Production, physicochemical characteristics and nutraceutical applications. Rev Virtual Quim 9(1): 387-409. https://doi.org/10.3390/molecules24010127

Henriksson, M.; Henriksson, G.; Berglund L.; Lindström, T. 2007. An environmentally friendly method for enzyme-assisted preparation of microfibrillated cellulose (MFC) nanofibers. Eur Polym J 43(8): $3434-$ 3441. https://doi.org/10.1016/j.eurpolymj.2007.05.038

Katakojwala, R.; Mohan, S. 2020. Microcrystalline cellulose production from sugarcane bagasse: Sustainable process development and life cycle assessment. J Clean Prod 249: 119342. https://doi.org/10.1016/j. jclepro.2019.119342

Kim, J.; Cai Z.; Lee, H.S.; Choi, G.S.; Lee, D.H.; Jo, C. 2011. Preparation and characterization of a bacterial cellulose/chitosan composite for potential biomedical application. J Polym Res 18(4): 739-744. https://doi.org/10.1007/s10965-010-9470-9

Lim, B.; Poh, C.; Voon, C.; Salmah, H. 2015. Rheological and thermal study of chitosan filled thermoplastic elastomer composites. Appl Mech Mater 754-755: 34-38. https://doi.org/10.4028/www.scientific.net/ AMM.754-755.34 
Liu, Y.; Lu, P.; Xiao, H.; Heydarifard, S.; Wang, S. 2017. Novel aqueous spongy foams made of three-dimensionally dispersed wood-fiber: entrapment and stabilization with NFC/MFC within capillary foams. Cellulose 24: 241-251. https://doi.org/10.1007/s10570-016-1103-y

Mathias, J.D.; Nicolas, T.D; Michaud, P. 2011. Development of a chitosan-based biofoam: application to the processing of a porous ceramic material. Int J Mol Sci 12(2): 1175-1186. https://doi.org/10.3390/ ijms 12021175

Mishra, P.; Ekielski, A.; Mukherjee, S.; Sahu, S.; Chowdhury, S.; Mishra, M.; Talegaonkar, S.; Siddiqui, L.; Mishra, H. 2019. Wood-based cellulose nanofibrils: haemocompatibility and impact on the development and behaviour of drosophila melanogaster. Biomolecules 9(8): 363. https://doi.org/10.3390/ biom 9080363

Mishra, P.; Gregor, T.; Wimmer, R. 2017. Utilising brewer's spent grain as a source of cellulose nanofibres following separation of protein-based biomass. BioResources 12(1): 107-116. https://ojs.cnr.ncsu.edu/ index.php/BioRes/article/view/BioRes_12_1_107_Mishra_Brewer_Spent_Grain_Cellulose/5545

Olorunsola, E.O.; Akpan, G.A.; Adikwu, M.U. 2017. Evaluation of chitosan-microcrystalline cellulose blends as direct compression excipients. J Drug Deliv 2017: 8563858. https://doi.org/10.1155/2017/8563858

Petersson, L.; Kvien, I.; Oksman, K. 2007. Structure and thermal properties of poly (lactic acid)/cellulose whiskers nanocomposite materials. Compos Sci Technol 67(11-12): 2535-2544. https://doi.org/10.1016/j. compscitech.2006.12.012

Sehaqui, H.; Zhou, Q.; Berglund, L.A. 2011. High-porosity aerogels of high specific surface area prepared from nanofibrillated cellulose (NFC). Compos Sci Technol 71(13): 1593-1599. https://doi.org/10.1016/j. compscitech.2011.07.003

Smith, M.; Love, D.C.; Rochman, C.M.; Neff, R.A. 2018. Microplastics in seafood and the implications for human health. Curr Environ Health Rep 5(3): 375-386. https://doi.org/10.1007/s40572-018-0206-Z

Stefanescu, C.; Daly, W.H.; Negulescu, I.I. 2012. Biocomposite films prepared from ionic liquid solutions of chitosan and cellulose. Carbohydr Polym 87(1): 435-443. https://doi.org/10.1016/j.carbpol.2011.08.003

Sundarraj, A.A.; Ranganathan, T.V. 2018. Comprehensive review on cellulose and microcrystalline cellulose from agro-industrial wastes. Drug Invention Today 10(1): 2783-2788. https://jprsolutions.info/article_detail.php?article_id=2739

Svagan, A.; Samir, M.; Berglund, L. 2008. Biomimetic foams of high mechanical performance based on nanostructured cell walls reinforced by native cellulose nanofibrils. Adv Mater 20(7): 1263-1269. https://doi.org/10.1002/adma.200701215

Trache, D.; Hussin, M.; Hui C.C.; Sabar, S.; Fazita, M.; Taiwo, O.; Hassan, T.; Haafiz, M. 2016. Microcrystalline cellulose: Isolation, characterization and bio-composites application-A review. Int J Biol Macromol 93: 789-804. https://doi.org/10.1016/j.ijbiomac.2016.09.056

Wang, Y.; Uetani, K.; Liu, S.; Zhang, X.; Wang, Y.; Lu, P.; Wei, T.; Fan, Z.; Shen, J.; Yu, H.; Li, S.; Zang, Q.; Li, Q.; Fan, J.; Yang, N.; Wang, Q.; Liu, Y.; Cao, J.; Li, J.; Chen, W. 2017. Multi-functional bionanocomposite foams using a chitosan matrix reinforced by nanofibrillated cellulose. Chem Nano Mat 3(2): 98-108. https://doi.org/10.1002/cnma.201700010

Yildirim, N.; Shaler, S.M.; Gardner, D.J.; Rice, R.; Bousfield, D.W. 2014. Cellulose nanolif (CNF) reinforced starch insulating foams. Cellulose 21: 4337-4347. https://doi.org/10.1007/s10570-014-0450-9 